\title{
LA RETIRADA (1939) E O EXÍLIO REPUBLICANO NO CAMP D'ARGELĖS-SUR-MER (FRANÇA) NA NARRATIVA AUTOBIOGRÁFICA DE UM EXILADO ESPANHOL ${ }^{1}$
}

\author{
GENY BRILLAS TOMANIK \\ Pontifícia Universidade Católica de São Paulo
}

RESUMO

\section{ABSTRACT}

Este artigo objetiva rastrear a trajetória e as experiências de um excombatente da Guerra Civil Espanhola, por intermédio das memórias de Pedro Brillas (1919-2006), que refletem vivências pessoais e coletivas, durante o êxodo republicano espanhol rumo à França, conhecido como La Retirada, e o exílio inicial dos refugiados no Camp D'Argelèssur-Mer, em 1939, em consequência da iminente derrota antifranquista, no fim da guerra. Por meio da narrativa autobiográfica do memorialista, estabelece-se um diálogo vívido com a historiografia contemporânea, espanhola e francesa, retratando dramas, adversidades e incertezas de milhares de retirantes espanhóis. Além disso, em seus escritos, afloram sensibilidades pessoais. O corpus documental é constituído dos textos autobiográficos de Pedro Brillas, composto de memórias, diários (inclusive da frente de batalha), cartas, entre outros. 0 precioso acervo relata experiências cotidianas e incomuns, subjetividades, além dos deslocamentos dos exilados espanhóis, vivenciados coletivamente. Geralmente guardados em baús e gavetas, esses materiais de e/ imigrantes recuperam e atualizam a memória individual e coletiva, representam um tesouro documental da produção de populares, muitas vezes invisivel, que ganharam valor na historiografia.

Palavras-chave: Autobiografia. Guerra Civil Espanhola. La Retirada. Camp d'Argelès-sur-Mer.

\section{LA RETIRADA (1939) AND THE REPUBLICAN EXILE IN CAMP D'ARGELĖS-SUR-MER (FRANCE) IN THE} AUTOBIOGRAPHICAL NARRATIVE OF A SPANISH EXILE

This article aims at tracing the trajectory and experiences of a former Spanish Civil War fighter, through the memoirs of Pedro Brillas (19192006), which reflect personal and collective experiences of the Spanish republican mass exodus to France, known as "La Retirada". It also

1 Este artigo integra a tese defendida em 27/03/2017 na Universidade Católica de São Paulo, sob o título de Memórias, deslocamentos, lutas e experiências de um exilado espanhol: Pedro Brillas (1919-2006). 
reports the exile of refugees in the Camp D'Argelès-sur-Mer in 1939, as a consequence of the imminent defeat of the Anti-Franco movement. Through the autobiographical narrative of the diarist, a lively dialogue is established with the contemporary Spanish and French historiography, depicting dramas, adversities and uncertainties of thousands of Spanish retreatants, complemented with personal sensibilities that are expressed in the text. The documentary corpus consists of the autobiographical texts of Pedro Brillas, composed of memories, diaries (including battle front journal) and letters, among others. This precious collection tells us about both trivial and unusual experiences, subjectivities, in addition to the description of the displacements of the Spanish exiles. Usually kept in chests and drawers, these e-immigrant materials recover and refresh both the individual and collective memory, and represent a trove of the popular production, often invisible, that has gained value in historiography.

Keywords: Autobiography. Spanish Civil War. La Retirada. Camp d'Argelès-sur-Mer.

\section{LA RETIRADA (1939) Y EL EXILIO REPUBLICANO} EN EL CAMP D'ARGELĖS-SUR-MER (FRANCIA) EN

\section{LA NARRATIVA AUTOBIOGRÁFICA DE UN EXILADO ESPAÑOL}

Este artículo objetiva rastrear la trayectoria y experiencias de un ex combatiente de la Guerra Civil Española, por intermedio de las memorias de Pedro Brillas (1919-2006), que reflejan vivencias personales y colectivas durante el éxodo republicano español rumbo a Francia, conocido como La Retirada y el exilio inicial de los refugiados en el Camp D'Argelès-sur-Mer en 1939, como consecuencia de la inminente derrota antifranquista al final de la guerra. Por medio de la narrativa autobiográfica del memorialista se establece un diálogo vívido con la historiografía contemporánea española y francesa, retratando dramas, adversidades e incertidumbres de miles de retirantes españoles, además, en sus escritos afloran también sensibilidades personales. El corpus documental está constituido de los textos autobiográficos de Pedro Brillas, compuesto de memorias, diarios (incluso del frente de batalla), cartas, entre otros. El precioso acervo relata experiencias cotidianas e inusuales, subjetividades, además de los desplazamientos de los exiliados españoles, vivenciados colectivamente. Generalmente guardados en baús y cajones, esos materiales de e/inmigrantes recuperan y actualizan la memoria 
individual y colectiva, representan un tesoro documental de la producción de populares, muchas veces invisibles, que ganaron valor en la historiografía.

Palabras-clave: Autobiografia. Guerra Civil Española. La Retirada. Camp d'Argelès-sur-Mer.

Durante a Guerra Civil Espanhola, a população hispânica sofreu as vicissitudes típicas de um conflito bélico: carestia, falta de gêneros alimentícios, fome, insegurança, incertezas, restrições dos serviços públicos, além dos bombardeios, tiroteios e atrocidades inenarráveis, cometidas por ambos os lados, além da divisão do país em franquistas e republicanos. Sobretudo, nos ataques a Madri, à Catalunha e na tomada de Barcelona pelos nacionalistas, em 26 de janeiro de 1939, intensificaram-se os bombardeios franquistas, apoiados pela Legião Condor de Hitler, acarretando o êxodo massivo rumo à França, conhecido como La Retirada.

A maré humana era constituída de homens, mulheres com seus filhos, idosos, mutilados e feridos de guerra, e o restante do Exército Popular, fatigados, maltrapilhos, sujos e desmoralizados pela iminência da derrota. Juntaram-se também ao fluxo multitudinário, rumo ao norte e à fronteira francesa, funcionários públicos e autoridades fieis à Segunda República Espanhola. Atravessaram a fronteira, no dia 5 de fevereiro de 1939, os presidentes Juan Negrín (Governo), Manuel Azaña (Presidente da República, Ministro da Guerra), Martinez Barrio (Presidente do Parlamento Espanhol), Lluís Companys (Presidente da Generalitat) e José Aguirre (Presidente do País Basco [ARANCIBIA, 2014]). O ex-presidente Azaña, que cruzou a fronteira no mesmo dia, em Montauban, faleceu no exílio, em território francês, no dia 3 de novembro de 1940, sendo enterrado no cemitério local (DEPORTADOS, 2015). Ou seja, três presidentes do governo da República morreram no exílio: além de Azaña, José Giral, no Mé- xico, em 1962, e Francisco Largo Caballero, em Paris, em 1946 (CASANOVA, 2013).

La poche catalane se refermant, la population civile, femmes, enfants, vieillards, blessés et invalides très vite rattrapés par les premières colonnes de l'armée républicaine, se ruaient vers le nord. Le grand exode des républicains espagnols commençait. ${ }^{2}$ (SAN GEROTEO, 2012, p. 99)

Estima-se em torno de 500.000 pessoas, que se viram obrigadas a evadir-se a caminho do país vizinho, a maioria seguindo a pé, pouco antes de uma guerra perdida: há dissonâncias sobre o número de refugiados republicanos, porém o êxodo espanhol para a França, em 1939, atingiu cerca de cinco centenas de milhares de pessoas, análogo à "Via-Crucis", tratando-se do "desterro de um povo", pois o seu exílio abrangeu o êxodo sem precedentes de milhares de espanhóis de todas as classes sociais (ALTED, 2012).

$\mathrm{Na}$ evasão massiva, foi utilizada toda espécie de veículos disponíveis: automóveis, caminhões, ônibus, carroças, bicicletas, além de animais como cavalos, burros e bois, que eram abandonados no caminho pela exaustão ou falta de combustivel, prosseguindo o percurso a pé, e gradativamente deixando para trás os seus pertences:

Llevando sólo lo que podían cargar, unas cuantas mudas de ropa, algunos juguetes (mi madre siempre recordará con mucho cariño, la muñeca de Shirley Temple que su hermano Salvador le

2 "O cinturão catalão se fechava. Civis, mulheres, crianças, idosos, feridos eram rapidamente ultrapassados pelas primeiras colunas do exército republicano rumo ao norte. 0 grande êxodo de espanhóis republicanos começava". (tradução livre) 
había regalado) y papeles; dejaron la casa para subirse en un camión de basura que un compañero anarquista había provisto limpio para el traslado a la frontera con Francia por donde habrían de cruzar en pleno invierno.3(ZARAGOZA OCAÑA, 2008, p. 15)

Outros depoimentos confirmam o ocorrido naquelas condições dramáticas. As escolhas do que levar consigo e o que abandonar eram cruciais, e totalmente pessoais, considerandose que cada indivíduo valoriza distintamente certos objetos entre os seus pertences, que eram selecionados não apenas por sua utilidade, mas muitas vezes pelo valor afetivo ou que remetem a experiências ou pessoas estimadas, as quais não desejam esquecê-las:

El calendario particular de cada persona se lleva en el corazón y nos sirve para medir el tiempo. Para mi abuela hubo momentos de su vida que la marcaron como si hubieran sido años [...] Esa guerra significó [para ella] perderlo todo, y su memoria en este punto, al igual que la memoria del mundo, se disolvió en humo. Sólo tenía conciencia de cómo tuvo que huir de su casa en Llanes, levando cosas para ella muy queridas, como sus cubiertos de plata, que pesaban tanto. [...] Pasó los Pirineos a pie, sin quitarse sus tacones, la abuela era asi presumida. Lamentablemente sus cubiertos fueron a parar a la nieve junto con las demás pertenencias de los refugiados que abandonaban España. De pronto los Pirineos se convirtieron en la tienda más grande y mejor surtida del mundo. Daba pena el desorden de la huida y la rapiña de los que teniendo coche iban quedándose con el botín. ${ }^{4}$ (María

3 "Levando apenas o que poderiam transportar, algumas mudas de roupas, alguns brinquedos (minha mãe sempre lembrará com grande carinho, a boneca de Shirley Temple que o irmão Salvador (he havia dado) e papéis; eles deixaram a casa para entrar em um caminhão de lixo que um companheiro anarquista havia fornecido limpo para a transferência para a fronteira com a França, onde eles atravessariam no meio do inverno" (tradução livre).

4 "O calendário particular de cada pessoa se leva no coração e nos ajuda a medir o tempo. Para a minha avó, houve momentos em sua vida, que a marcaram como se tivessem sido anos [...] Essa guerra significava [para ela] perder tudo, e sua memória nesse ponto, como a memória do mundo, dissolveu-se em fumaça. Ela
Victoria García apud ALTED, 2012, ebook, pos. 567-576)

Assim, foram inúmeras as diversidades enfrentadas pelos refugiados, entre elas o abandono das suas casas, bem como dos seus pertences pessoais, com valor sentimental e capazes de recuperar a memória familiar, além do bombardeio dos franquistas, com o apoio da Legião Condor, sobre a população e das inclemências de um rigoroso inverno, não apenas durante a travessia das montanhas geladas, bem como logo após o êxodo. Somava-se a isso a fome, a repentina separação dos familiares, ao cruzarem a fronteira, de acordo com as determinações das autoridades francesas, e ainda um futuro incerto, que lhes marcaria definitivamente, dando vazão à memória coletiva do exílio (E-XILIAD@S, s/d.).

Entre o final de 1938 e início de 1939 chegaram à fronteira franco-hispânica os primeiros retirantes que tiveram de aguardar o seu acesso pelas autoridades francesas. Entre eles encontravam-se Pedro Brillas e o seu companheiro Antonio, os quais, segundo suas memórias, esperaram três dias para passar pelo posto fronteiriço de Le Perthus (figura 1, a seguir), França, onde foram obrigados a entregar suas armas, pois "Os fugitivos republicanos foram revistados minuciosamente pelos guardas ao passar pelos controles fronteiriços. O objetivo era desarmar os refugiados, muitos dos quais tinham passagem pelo Exército Popular" (BUADES, 2013, p. 303), como era o caso dos dois compatriotas.

\footnotetext{
apenas estava ciente de como ela tinha que fugir de sua casa em Llanes, carregando coisas muito queridas para ela, como seus talheres de prata, que pesavam tanto. [...] Ela passou pelos Pirenéus a pé, sem tirar os saltos altos, a avó era tão convencida. Infelizmente, seus talheres foram para a neve junto com outros pertences dos refugiados que estavam deixando a Espanha. De repente, os Pirenéus se tornaram a maior e mais bem abastecida loja do mundo. Dava piedade da desordem da fuga e do assalto por aqueles que, tendo um carro, ficavam com o saque“ (tradução livre).
} 
Figura 1 - Passagem dos refugiados espanhóis por Le Perthus, 1939 (recorte).

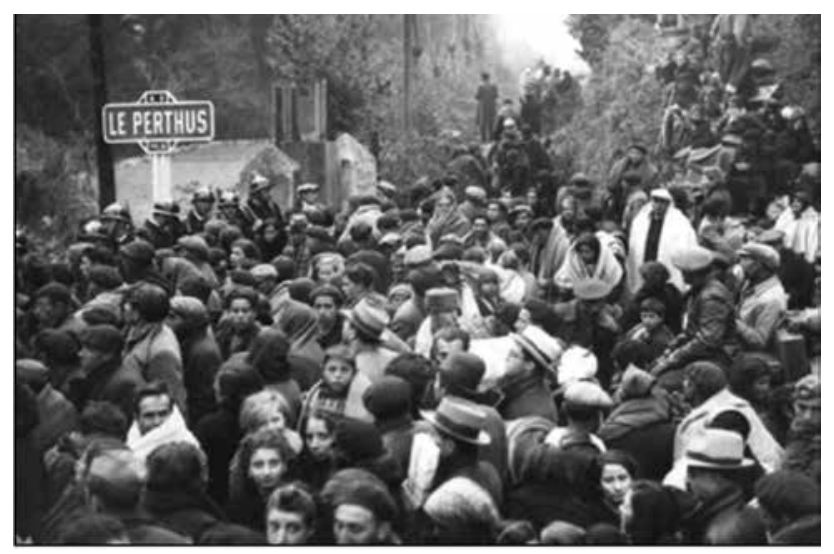

Fonte: MICKAEL, Martins. La Retirada. Vídeo sobre a Retirada espanhola em 1939. Disponivel em: <http://www. eclectique.net/histoires_histoire/themes5.html>. Acesso em: 24 mar. 2015.

Los primeros refugiados llegaron a finales de 1938 y principios de 1939. La caída de Cataluña en manos de los falangistas, el 26 de enero de 1939, fue el inicio del éxodo masivo. En un primer momento, y ante la imprevista afluencia de militares y civiles, el gobierno del Front Populaire propuso a Franco organizar una zona neutral, entre Andorra y Port-Bou, iniciativa a la que el dictador se negó, considerando a los huidos como prisioneros de guerra. El 27 de enero, el gobierno francés abrió completamente la frontera, en principio solo para civiles, guardias móviles y el 24 regimiento de tiradores senegaleses. A su llegada a territorio francés, a los refugiados se les despojaba de todo cuanto llevaban encima: armas, y también joyas y dinero. ${ }^{5}$ (ARANCIBIA, $2014 \mathrm{~s} / \mathrm{p}$.)

Com o objetivo de registrar a Guerra Civil Espanhola e o êxodo republicano, a imprensa somava-se à multidão ou aglomerava-se

5 "Os primeiros refugiados chegaram no final de 1938 e no início de 1939. A queda da Catalunha nas mãos dos falangistas, em 26 de janeiro de 1939, foi o início do êxodo em massa. No primeiro momento, ante do fluxo inesperado de militares e civis, o governo da Frente Popular propôs a Franco organizar uma zona neutra, entre Andorra e Port-Bou, cuja iniciativa o ditador recusou, considerando os refugiados como prisioneiros de guerra. Em 27 de janeiro, o governo francês abriu completamente a fronteira, inicialmente apenas para civis, guardas rodoviários e o 24 o regimento senegalês. Ao chegarem no território francês, os refugiados foram despojados de tudo o que carregavam: armas, jóias e dinheiro" (tradução livre). na fronteira. O deslocamento multitudinário foi amplamente registrado e fotografado pela imprensa internacional, ${ }^{6}$ denotando a relevância do episódio também internacionalmente. Cabe ainda destacar o trabalho fotográfico do renomado Robert Capa, que, além da Guerra Civil Espanhola (batalha do Rio Segre) e do êxodo republicano, fotografou também as condições a que foram submetidos os refugiados no Camp d'Argelès. São significativos os extratos do diário de Capa sobre a Retirada:

El gener del 1939, quan Barcelona havia caigut en mans dels feixistes, els 150 quilòmetres de carretera que separen Barcelona de la frontera francesa havien estat envaïts per una munió de persones que fugien de les legions estrangeres de Franco. Intelectuals i obrers, pagesos i comerciants, mares, dones i mainada havien seguit o passat al davant dels darrers vehicles de l'exèrcit republicà a la desbandada. Carregant els seus farcells a l'esquena i amb la roba feta parracs, els seus peus els havien portat cap a la França de la libertat democrática.? (GAILLARD, 2015)

6 Entre 27 de janeiro e 10 de fevereiro, a Retirada foi assunto da imprensa internacional. A partir do dia 28 de janeiro de 1939, um grupo de mais de 135 jornalistas chegou a Roussillon (França) para informar os leitores a respeito do grande evento da política internacional, que anunciava a queda da República espanhola. Muitos jornalistas estavam presentes na fronteira catalã e realizaram uma série de reportagens, como as agências fotográficas Fulgur, Keystone e a reportagem da Wide World Photo for The New York Times sob o título "De la caiguda de Barcelona a 'La Retirada"' ("Desde a queda de Barcelona à 'La Retirada"). A reportagem e as fotografias da Photo NYT (clicadas por Capa, Chim e Chauvin) permaneceram inéditas até a exposição de 42 fotografias originais, apresentadas pela Casa de la Generalitat de Catalunya, em Perpignan, que permitiram redescobrir um patrimônio visual essencial da história do século XX. De 24 de janeiro a 22 de março de 2015 encontravam-se em exposição no MUME (Museu Memorial de l'Exili). Cf.: MUME, s/d.

7 “Em janeiro de 1939, quando Barcelona caiu nas mãos dos fascistas, os 150 quilômetros de estrada que separam Barcelona da fronteira francesa foram invadidos por uma multidão de pessoas que fugiam das legiões estrangeiras de Franco. Intelectuais e trabalhadores, agricultores e comerciantes, mães, mulheres e crianças haviam seguido ou ultrapassado os últimos veículos do exército republicano, que estava em debandada. Levando pacotes em suas costas, com roupas em farrapos, seus pés os haviam levado à França da liberdade democrática". (tradução livre) 
Para os hispânicos antitotalitaristas, a França significava um refúgio seguro e natural, por ser uma fronteira seca e, portanto, mais viável: "Ils attendaient comme tout un chacun la marche forcée vers le nord, où un peuple frère les accueillerait. Cette grande espérance, le refuge en territoire français, semblait tellement naturelle à tous ces républicains bourrés de renoncements mais l'espoir au cœur"8 (SAN GEROTEO, 2012, p. 99). Além disso, era considerada um país amigo, reconhecido como terra de liberdade e da ideologia republicana, a partir da Revolução Francesa (1789), com o lema "Liberdade, igualdade, fraternidade" (Liberté, égalité, fraternité) e da Declaração dos Direitos Humanos.

"La masa de la población civil seguía un impulso colectivo"9 (PÀMIES, 1976, p. 12), alguns com a expectativa de encontrar na França marido, filhos, irmãos (ex-combatentes republicanos) e de, passado o confronto, poder recomeçar a vida.

No princípio de fevereiro de 1939, o Exército Popular, presente no território catalão, encontrava-se em plena retirada. A multidão, integrada também por civis, tomou as cidades de Girona e Figueres ${ }^{10}$ e as estradas de acesso à França, sendo perseguida pelos bombardeios aéreos das forças franquistas, com o apoio das aviações italiana e alemã.

Desde mediados de enero las carreteras que conducian a Francia rebosaban de gentes hambrientas, aturdidas, que, con las escasas pertinencias que podían arrastrar consigo, trataban de alcanzar la frontera bajo la lluvia, el frío, la nieve, el viento y, sobre todo, las

8 "Eles estavam esperando como se fossem apenas um, a marcha forçada rumo ao norte, onde uma população irmã os acolheria. Esta grande esperança, o refúgio em território francês, parecia verdadeiramente natural a todos esses republicanos com tantas renúncias, mas com esperança em seus corações". (SAN GEROTEO, 2012, p. 99, tradução livre)

9 "A massa da população civil seguia um impulso coletivo" (tradução livre).

10 Entre eles, Pedro e o seu novo amigo Antonio. bombas.11 (ALTED, 2012, ebook, pos. 498)

Desta forma, a fuga massiva rumo à fronteira francesa foi realizada sob condições penosas, com privações e constantes perigos. Além disso, após um longo e dramático percurso exílico, frustraram-se as suas expectativas de segurança e de um acolhimento digno por parte das autoridades francesas.

Figura 2 - Família Gracia, 1939.

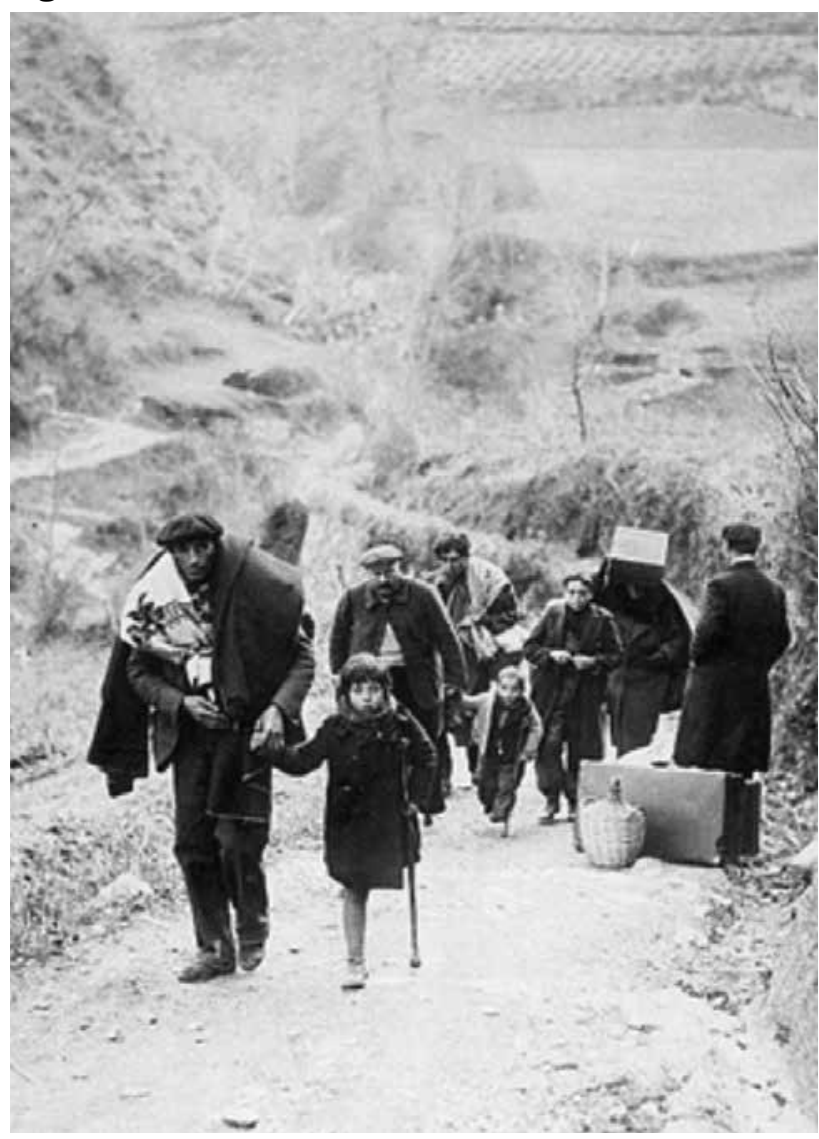

Fonte: L'ILLUSTRATION. Paris, no. 5.007, 18 fev. $1939 .^{12}$

Os refugiados hispânicos sofreram toda espécie de arbitrariedades: primeiramente, a longa espera para obterem permissão de cruzar a fronteira francesa, seguida da revista,

11 "Desde meados de janeiro, as estradas direcionadas rumo à França estavam cheias de pessoas famintas e aturdidas, com seus poucos pertences que podiam levar consigo, tentavam chegar à fronteira sob chuva, frio, neve, vento e, sobretudo, sob as bombas"(tradução livre).

12 Esta fotografia, publicada na revista L'Illustration, em matéria sobre a Retirada, tornou-se emblemática do êxodo espanhol de 1939 em direção à França. Quase todos da família Gracia foram mutilados por uma bomba em Huesca, quando a mãe os protegeu com o seu próprio corpo e morreu. 
apreensão de armas e joias, e ainda pior, a separação dos familiares, além da longa caminhada até o Camp d'Argelès-sur-mer, um campo de detenção improvisado nas areias da praia, para abrigar o fluxo de milhares de refugiados. Foram conduzidos rudemente pelos gendarmes ${ }^{13}$ ou por soldados armados das forças coloniais francesas, sob a ordem de prosseguir: “Allez, allez!" - repetida insistentemente durante a caminhada, desde a fronteira até o campo de internamento - e que se tornou um bordão inesquecivel e "maldito" (PEDRO BRILLAS, 1965) do exílio inicial para os refugiados republicanos, citado e relembrado nas memórias, canções e poemas, por autores:

Canción de los Refugiados ${ }^{14}$

Somos los tristes refugiados

a este campo llegados

después de mucho andar

hemos cruzado la frontera

a pie y por carretera

con nuestro ajuar

Mantas, macutos y maletas

dos latas de conserva

$y$ algo de humor,

es lo que lo hemos podido salvar

después de tanto luchar

contra el fascio invasor.

Y en la playa de Argelès sur Mer,

nos fueron a meter

i pa no comer!

$Y$ pensar que hace tres años

España entera

era una nación feliz,

libre y prospera;

abundaba la comida,

no digamos la bebida,

el tabaco y el 'parné'.

Había muchas ilusiones

13 Policiais militares franceses.

14 Canção escrita pelos refugiados do campo d'Argelèssur-Mer, sendo que há diversas versões. (LANIER, 2000-2001) la paz en los corazones

y mujeres a granel...

y hoy que ni cagar podemos

sin que venga un 'Mohamed'15,

nos tratan como a penados

y nos gritan los soldados...

¡Allez!... Allez!

Vientos, chabolas incompletas,

Ladrones de maletas,

jarena y mal olor!

Mierda, por todos los rincones,

Sarna hasta los cojones,

¡Fiebre y dolor!

Y alambradas para tropezar,

De noche al caminar

Buscando tu 'chalet'

Y por todas partes donde vas,

Te gritan por detrás...

¡Allez!... ¡Allez!...

Y si vas al 'barrio chino',

Estas 'copado',

Te quedas sin un real...

¡y cabreado!

Tres cigarros mil pesetas

y en juego no te metas

porque la puedes 'palmar'

y si tu vientre te apura

y a la playa vas, oscura,

te pueden asesinar...

En mal año hemos venido, no sabemos ya que hacer, cada día sale un 'bulo'

y al final te dan por el culo

¡Allez!... ¡Allez!...

Essa canção resume as experiências, "dramas" e humilhações a que foram submetidos os retirantes espanhóis, como se verá nos relatos de Pedro Brillas, a seguir.

15 Soldados das tropas coloniais francesas que vigiavam o campo. 


\section{Escrita de si de populares}

Es tarea más ardua honrar la memoria de los seres anónimos que la de las personas célebres. La construcción histórica se consagra a la memoria de los que no tienen nombre. ${ }^{16}$

Pedro iniciou a escrita de si, muito jovem, e as suas memórias, em 24 de janeiro de 1938, com apenas 18 anos, são um fato singular para a idade. No excerto extraído do manuscrito Mis memorias de sua autoria, em janeiro de 1938, em Barcelona, observa-se que a Guerra Civil Espanhola e as suas experiências como combatente foram o gatilho motivador para a escrita de si, mantida e atualizada ao longo de aproximadamente 70 anos, até o seu falecimento em 2006, pois guerras, revoluções, conflitos bélicos são eventos inesquecíveis na memória individual e coletiva, mesmo que muitos prefiram esquecê-los e silenciar a respeito.

Cabe esclarecer que o autobiógrafo escrevia e reconstruía a sua autobiografia ${ }^{17}$ na forma de diários, memórias manuscritas em cadernos, cadernetas ou datilografadas, apontamentos, cartões postais, cartas, formando um mosaico da escrita de si. Muitos dos seus manuscritos em cadernos escolares não foram finalizados e se extraviaram, porém, o autor reiniciava os seus registros, alguns a partir da sua infância pobre em Barcelona, outros a par-

16 “É mais árdua a tarefa de honrar a memória de seres anônimos do que a de pessoas célebres. A construção histórica é dedicada à memória daqueles que não têm nome". Essa citação de Walter Benjamin encontra-se gravada no monumento comemorativo "Passages", dedicado ao autor, em Port Bou, na fronteira com a França, onde se refugiou em 1940 das tropas nazistas e, supostamente, teria cometido suicídio com uma dose mortal de morfina. (MOLINA, 2012)

17 Entende-se autobiografia como o conjunto de escritos autorreferenciais que relatam sobre a sua trajetória, experiências e sensibilidades. Além dessas escrituras, cabe salientar que a memória de si também engloba a coleção de objetos, como fotografias, esquemas, desenhos, documentos pessoais e oficiais, entre outros bens pessoais, que também evidenciam a história do indivíduo e dos grupos aos quais se integrou, constituindo um "teatro da memória", que possibilita a sua preservação por um prazo maior do que o tempo biológico de uma vida humana. Cf.: GOMES, 2004. tir da Guerra Civil Espanhola, e alguns poucos a partir do exílio forçado, como consequência do conflito (figura 3, a seguir).

Figura 3 - Manuscrito (em espanhol) de Pedro Brillas sobre o Exílio.

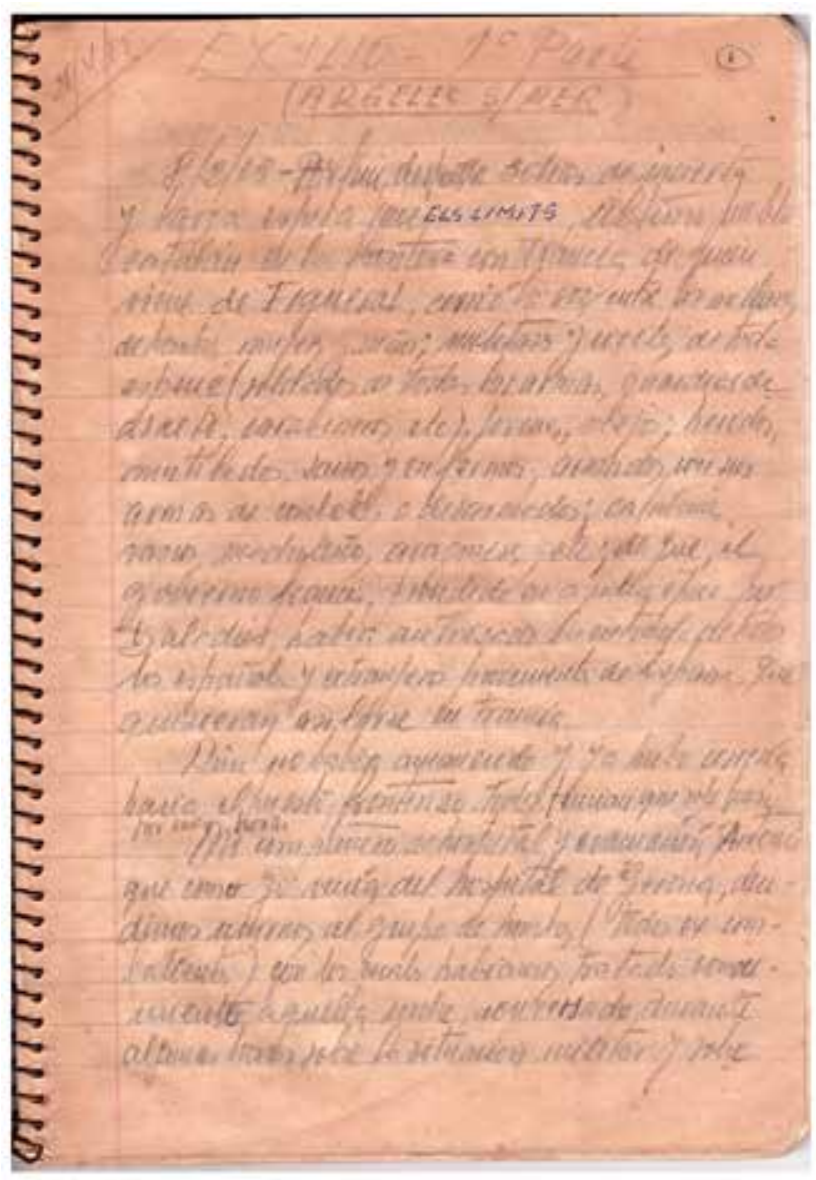

Fonte: Pedro Brillas, 1965, p. 1.

Além disso, durante quase sete décadas ele re/construiu e atualizou a sua memória (POLLAK, 1992), arquivou a sua própria vida (ARTIÈRES, 1998; 2013), foi um guarda-memória (LEJEUNE, 1997), formando o seu amplo arquivo pessoal (TRAVANCAS, 2013). Todavia, durante as guerras na Europa, Pedro perdeu todos os seus pertences, inclusive os seus diários. Dispõe-se de fragmentos de diários das bataIhas, os quais provavelmente deixou na casa da mãe, durante licença, e foram recuperados 30 anos depois. Cabe ressaltar que iniciou os seus manuscritos em espanhol, e na dúvida sobre em qual idioma prosseguir, optou pelo "portunhol", conforme registrou. 
Atribui-se a recorrente escrita de si à sua busca na constituição de si, pois era órfão de pai, aos três meses de vida, e sentia um vazio sobre a figura paterna, e com essa prática buscava a constituição de si, estabelecendo uma relação de si consigo mesmo (FOUCAULT, 2006). Além disso, pretendia deixar como legado aos seus descendentes as suas memórias, experiências e sensibilidades, para que não tivessem essa lacuna. Aliás, eram recorrentes os seus relatos orais daqueles momentos, à família e amigos, porém não se vitimizava, mas destacava com bom humor que era um homem de sorte, pois havia sobrevivido a tantos perigos.

Cabe destacar que os assim denominados "escritos ordinários" (CHARTIER, 1991) ganharam relevância na historiografia como forma de proporcionar visibilidade aos textos, inclusive autobiográficos, de pessoas anônimas, anteriormente desprezadas ou utilizadas apenas como fontes alternativas (CASTILLO GÓMEZ, 2001). Esses escritos refletem experiências cotidianas e/ou incomuns, e transitam entre questões de fórum íntimo e público (ARFUCH, 2010a; 2010b) que representam um patrimônio da escritura e da memória popular, como é o caso dos textos de Pedro Brillas. Além disso, o imigrante ou exilado é um observador privilegiado dos deslocamentos in/voluntários e cujas escrituras refletem experiências coletivas e privadas.

Existem fatos marcantes vivenciados por milhares de indivíduos, mas cada um possui a sua própria visão e sensibilidade, e esse é o aspecto que constitui a riqueza dos documentos e testemunhos de populares, pois não pretendem articular uma verossimilhança comum a todos, todavia, buscam o entendimento da sua relação pessoal com os acontecimentos e a socialização das suas vivências, e, por vezes, um possivel diálogo historiográfico para apaziguar as suas inquietações e lembranças.
Faz-se necessário salientar que o autobiógrafo, aqui citado, estabeleceu um "pacto autobiográfico" (LEJEUNE, 2008), ao manter um diálogo vívido com um suposto leitor, e ao dedicar as suas memórias "a todos que se interessarem por mim".

\section{Memórias, experiências e estratégias de sobrevivência: La Retirada}

Pedro Brillas, o jovem combatente antifranquista catalão, foi ferido em combate, na batalha do Rio Segre, em dezembro de 1938, próximo ao fim da Guerra Civil Espanhola e da derrota republicana. Por fim, Pedro e Antonio, seu novo amigo, também ferido, conhecido durante o transporte até um último Hospital em Ollot, observaram o êxodo massivo republicano rumo à França. O memorialista descreve o momento, corroborando autores e depoimentos citados:

[sic] Subimos uns 20 homens em cada caminhão, no qual a maioria sentou-se no chão da carroceria, e alguns em pé segurando na cobertura da cabine. Antes de subir recebemos um pacote cada um com comida $\mathrm{p} /$ a viagem. Rodamos durante várias horas, no começo por estrada asfaltada, estadual, e depois por estradas vizinhais, também asfaltadas, mas maís estreitas. Durante o percurso passamos por caminhões, ônibus, e alguns carros, e bastantes carroças puxadas a cavalo e mula, com camponeses que se dirigiam rumo a fronteira. As tais carroças, estavam carregadas c/ moveis, roupa, utensílios de cozinha, e coisas de valor sentimental da família. (Pedro Brillas, [199-?]a, p. 73)

Após passarem por consulta médica naquele hospital mais próximo à fronteira francesa, ambos foram liberados para tomarem o rumo desejado, por sua conta e risco. Juntos decidiram apresentar-se ao quartel general mais próximo, em Girona, para seguir instruções. Vale salientar que embora Pedro fosse 
anarquista e, portanto, contrário à hierarquia de um exército, se atinha às normas militares, e mais ainda o seu amigo Antonio, comunista e "comissário político". Neste contexto, o autor elucida:

[sic] Devo esclarecer, ${ }^{18}$ que ao ser formado o Exército Popular Espanhol, ou seja, o nosso, este estava baseado na estrutura do exército da UNIÃO SOVIETICA pois que por aquele tempo, os comunistas espanhóis, apoiados e instruídos por Moscou, praticamente dominavam os ministérios mais importantes do governo republicano espanhol, amparando-se em que os russos eram nossos principais fornecedores de material de guerra e outros suprimentos necessários para nossas forças. Assim sendo, cada Cia. tinha um 'Comissario Politico', encarregado de manter a moral da tropa, e em principio, ao qual os soldados podiam reclamar. Este Comissario não participava, teoricamente, da estratégia militar, mas geralmente nas Cias da 121a. Brigada, era consultado pelo capitão. Daí que meu novo companheiro andava influído pela doutrina comunista, e continuava com entusiasmo combativo. (Pedro Brillas, [199-?]a, p. 77).

Seguiram a estrada a pé e o fluxo de soldados e civis, muitos deles caminhando, carregando trouxas, malas, mochilas, empurrando ou puxando charretes carregadas com roupa, alimento etc., em carroças puxadas por cavalos ou mulas, algumas puxadas por bois, evidenciando que eram camponeses, além de caminhões, ambulâncias, ônibus, inclusive de Barcelona. Dessa forma, ambos, integrados à multidão, encontravam-se em plena Retirada.

Caminharam em passo lento, devido à condição de Antonio, que necessitava apoiar-se em um cajado. Ao avistarem algum caminhão, faziam sinal para parar, mas nenhum os atendia, pois já estavam lotados. Andaram todo o dia e a noite inteira; no trajeto detinham-se para descansar e alimentar-se de alguma fruta

18 Pode-se observar que frequentemente Pedro "dialoga" com um suposto leitor, estabelecendo um "Pacto autobiográfico" entre narrador/personagem e leitor. (LEJEUNE, 2008) ou legume que apanhavam nos campos abandonados ao longo da estrada, da mesma forma que outros retirantes. Os legumes eram fervidos em uma lata, consumidos sem sal ou tempero. Pedro já sentia falta das refeições dos hospitais, pois novamente encontrava-se faminto, e lembrava-se dos dias difíceis no front, com a carência de alimento.

De vez em quando, ouviam disparos de artilharia, geralmente na retaguarda, mas também à frente, o que os fazia acreditar que os nacionalistas tentavam impedir sua chegada à fronteira. Após 24 horas, chegaram a Figueres, ou seja, o trajeto percorrido por Pedro e Antonio, a partir de Olot (Girona), totalizava aproximadamente $49 \mathrm{~km}$. Ao chegarem em Figueres, apresentaram-se ao alto comando do exército, e solicitaram instruções ao capitão, por estarem ambos feridos na guerra.

[sic] Enterado do nosso estado físico, e de que não estávamos ainda em condições de voltar as nossas Cias, o capitão sinceramente falou $\mathrm{p} /$ nós, que do jeito que estava a situação guerreira, habendo retirada das tropas legais em todos os fronts, estando o enemigo avançando rapidamente na nossa direção, ou seja, para a fronteira, e ele não vendo possibilidade de o parar, deixava a nosso critério o caminho a tomar, o da fronteira, para onde iam milhares de homens (soldados ou civis), mulheres e crianças, ou voltar $\mathrm{p} /$ nossas casas, ou ir $\mathrm{p} / \mathrm{o}$ sul $\mathrm{e}$ tentar achar nossas Cias, que êle ignorava onde estavam. Para êle, o melhor caminho era o da fronteira, pois que nossa derrota total, não tardaria, pois as forças franquistas, dispunham de muito mais e melhor armamento e tropas que nós. (Pedro Brillas, [199-?]a, p. 80-81)

Os amigos espanhóis seguiram a recomendação do capitão e prosseguiram no êxodo, denotando a relevância que atribuíam ao comando militar antifranquista. Percorreram as ruas da cidade, na busca de um lugar para descansarem, e por fim, perto da periferia, encontraram um palheiro com portas abertas, onde já havia outros jovens. Resolveram juntar-se 
ao pessoal, quase todos de Barcelona, também a caminho da França. Acomodaram-se em um pequeno monte de palha cada um, para descansar, no andar superior. Repentinamente, já adormecidos, foram sacudidos por explosões de bombas, barulho de aviões sobrevoando a pequena cidade e disparos de artilharia antiaérea. Pedro relembra:

[sic] Rápidamente pegamos nossos pertences, descemos até a rua, e corrimos na direção dos campos, onde nos deitamos no chão. Foram jogadas varias bombas no centro da cidade, quiçás no quartel, onde nós tínhamos estado não fazia muito tempo. Vimos algumas explosões e incêndios, e as granadas antiaéreas explodirem no ar, não longe dos aviões enemigos dos quais não vi nenhum ser derrubado. (Pedro Brillas, [199-?]a, p. 82)

Novamente, Pedro sobreviveu aos perigos do conflito. Após o breve bombardeio, retornaram ao palheiro, onde haviam deixado os seus pertences, inclusive material para a escrita epistolar e anotações; surpreende o fato do autor lembrar-se de tantos detalhes, passadas tantas décadas, talvez consultados em registros anteriores, não mais disponiveis no acervo:

[sic] Eu tinha uma pequena mochila contendo papel, envelopes e canetas, uma muda de roupa interior, 2 pares de meias, lenços, escova de dentes com pasta, e barbeador Gillete, sabão e pincel $p /$ fazer a barba, e outras quincalherias. Também tinha um (tabardo?) ${ }^{19} \mathrm{e}$ um cobertor, que tinha recebido no hospital de Manresa, pois que ao ser ferido no front perdi tudo. (Pedro Brillas, [199-?]a, p. 83)

Os dois averiguaram que suas coisas ainda estavam lá e as demais pessoas haviam retornado, esconderam os seus poucos pertences embaixo da palha e saíram em busca de alimento. Nas ruas próximas, notaram várias ca-

19 Transcrição literal da palavra, escrita pelo autor em parênteses e com ponto de interrogação. "Espécie de capote com capuz abotoado e mangas". (INSTITUTO ANTÔNIO HOUAISS, 2012) sas destruídas, seguramente em bombardeios anteriores, segundo Pedro, pois não se notava fumaça. As casas - próximas da periferia eram campestres, a maioria com estábulo para carroças e cavalos, além de alguns sobrados antigos, malcuidados.

[sic] De repente, ao entrar numa rua, percebemos gente carregando sacos, panelas, utensílios diversos, legumes, etc. os quais saiam duma casa. Na realidade um monte de gente, militares e civis, estava saqueando uma casa que seguramente estava abandonada, ou fazia, pouco tempo por causa do bombardeio, ou já muito, os moradores, tinham abandonado o lugar. (Pedro Brillas, [199-?]a, p. 84)

Aproximaram-se da entrada da casa típica de camponeses. Quando todos saíram, adentraram pela porta escancarada e notaram que havia grãos de milho, arroz, cevada, entre outros, espalhados pelo chão e, em uma sala espaçosa com mesa e cadeiras, um armário totalmente aberto com gavetas no chão e muitas roupas e panos desordenados. Concluíram que a casa havia sido saqueada e que não havia mais ninguém por perto. Ao chegarem à cozinha avistaram uma lareira apagada. Pedro relata em detalhes o cenário e mais uma experiência inesquecivel:

[sic] Hachamos dentro duma lata de folha de Flandres, uns restos de arroz, misturados com massa triturada, um tomate, dos que na Catalunha se penduravam na cozinha $\mathrm{p} /$ deixar meio secar, e que se usa $\mathrm{p} /$ fazer molho, sal, 2 dentes de alho, uma cebola pequena, e numa garrafa de vidro, no fundo um pouco de aceite. Verifiquei que no fogão, que era de tijolos com 4 buracos c/ grelha, que funcionava a lenha ou carvão vegetal, tinha uns restos apagados de carvão, e na pia ao lado do fogão uma torneira de metal, que abrí e jorrou agua, na qual numa vasilha de louça meio quebrada, lavei todo o achado. Hachei uma velha frigideira não muito grande, meio sucia, que também lavei, e acendí o carvão na base de papel de jornal que estava no chão, e fósforos que estavam num canto do 
fogão. [...]. Consegui cozinhar na frigideira algo palatável, tendo em vista a fome que eu particularmente e Antonio sentíamos, distribuídos em dois pratos de louça meio quebrados e nos sentamos ao lado da mesa, em duas cadeiras, também quebradas, más que nós conseguimos equilibrar com ladrilhos. [...] Fazia poucos minutos que estávamos la sentados e comendo (ainda não tínhamos terminado pois a comida estava muito quente), quando de repente escutamos barulho nas nossas costas, e uma voz gritando: Mãos para cima!! Vocês estão presos! (Pedro Brillas, [199-?]a, p. 85-87)

Foram surpreendidos por soldados armados com fuzis e um sargento, além de um homem civil que gritava como louco, chamando -os de ladrões. O sargento deu voz de prisão, pois eram acusados de saqueadores. Foram revistados, verificando-se o que tinham nos bolsos: apenas lenço, canivete, revólver e miudezas.

O sargento então os questionou sobre o que faziam ali. Antonio respondeu que eram soldados e o ocorrido desde a saída do Hospital de Olot até aquele momento. Apesar dos pedidos insistentes dos dois companheiros, não permitiram que finalizassem a refeição, foram levados até o mesmo quartel onde horas antes haviam se apresentado, ao mesmo capitão com quem já tinham conversado, o qual se surpreendeu, ainda mais, ao tomar conhecimento do motivo do retorno:

[sic] Puxa vida, de novo vocês! Eu pensava que vocês já estavam na fronteira. Olha, o vosso caso é gravíssimo. Vocês foram pegos dentro d'uma casa saqueada, e portanto vocês são considerados saqueadores, e como tais em tempo de guerra, e como militares, sujeitos à pena de morte, por fuzilamento. Eu tenho que fazer um relatório, que vou encaminhar ao comandante da praça, que é um general, e êle vai decidir. [...] Chamou de novo o sargento com quem falou, pedindo 2 soldados armados $\mathrm{p} /$ nos vigiar enquanto êle, falava com o general. [...] Meia hora +-, voltou o capitão, desta vez, acompanhado do general e mais um oficial. o general era um homem de uns 60 anos, cabelos grisalhos, cara rosada, demonstrando que ficava mais tempo dentro do quartel, que fora ao ar livre. 0 aspecto dele era simpático. Todo o pessoal que estava na sala do capitão, ao ver o general, fizemos continência, correspondida brevemente pelo general, levando sua mão direita, perto da cabeça. (Pedro Brillas, [199-?]a, p. 89-91)

Pedro e Antonio foram interrogados pelo general, que aparentemente já havia sido informado do caso pelo capitão - como tinham se ferido, o que estavam fazendo em Figueres, por que se encontravam na casa saqueada e o fato de que não haviam furtado nada. Segundo o autor, Antonio, mais graduado do que ele, era quem respondia ao interrogatório. Apesar do flagrante, o general os livrou de fuzilamento, talvez por considerar o caso sem importância, segundo Pedro, que ainda esclarece o desenrolar do acontecimento e o contexto bélico:

[sic] $\mathrm{Na}$ realidade, o exército republicano na zona nordeste (Catalunha), estava em franca retirada, e possivelmente as tropas franquistas chegariam à Figueres em poucos dias, portanto nada se ganhava nem perdia, se nós fossemos ou não fuzilados como saqueadores. Assim sendo, e não tendo roubado nada a não ser um pouco de comida, êle preferia nos dar uma chance, libertando-nos para que fóssemos $p /$ onde quiséssemos. Deu ordens $p /$ que fossem devolvidos nossos revólveres, e que também nos fosse dado algo $\mathrm{p} /$ comer, e fazendo meia continência abandonou a sala, junto $\mathrm{c} / \mathrm{o}$ oficial, ficando pois, Antonio, eu, o capitão, e os dois soldados. (Pedro Brillas, [199-?]a, p. 93)

Cabe ressaltar que esse episódio é um dos mais marcantes da memória familiar, pois $\mathrm{Pe}$ dro costumava contá-lo aos familiares e amigos, nos mínimos detalhes, sem amargura, nem mesmo se vangloriar, mas como um momento de sorte, pois novamente escapara da morte. 0 depoimento acima espelha tensões possiveis em tempos de conflitos bélicos, e a dependência do arbítrio de autoridades constituídas, além de retratar que certas estraté- 
gias de sobrevivência podem resultar em riscos pessoais.

Solidariamente, o capitão ordenou que fossem entregues aos dois amigos um "chusco" (pão militar) e uma lata de carne russa em conserva. Retornaram ao palheiro e recordaram a aventura e o perigo ao qual sobreviveram, como "um grande susto". Cerca de uma hora após, Pedro já adormecendo, foi surpreendido pelo assédio de uma garota de uns 16 anos, que fazia parte do grupo de jovens, e que, ao se encontrar só, se juntou a ele, beijou -o e deu-lhe momentos de prazer (Pedro Brillas, [199-?]b, p. 2).

Foram muitas ocorrências durante La Retirada, vivenciadas pelos espanhóis: perigos, tensões e incertezas, essas reforçadas por boatos, que corriam solto entre os refugiados. Ademais, trocavam-se pequenos favores, rumores, dúvidas, além de momentos íntimos com desconhecidos, impensáveis em tempos de paz. Pedro trocou intimidades diferentes com duas moças, durante o percurso:

[sic] Curioso. En menos de 1 semana habia conocido dos mujeres. Ambas de la misma edad. Bonitas. Con las dos solo estuve unas horas junto. De la primera que poseí durante 1 hora, apenas recuerdo su rostro y nombre. Solo recuerdo que era rubia y si no me falta la memoria se llamaba Fernanda. De la segunda guardo un grato recuerdo sin haberla siquiera besado. Con la primera, tuve comunión de cuerpo, con la segunda, comunión de alma. Ambas fueran meteoros en el camino de mi vida, y en cambio que diferencia. (Pedro Brillas, 1965, p. 3-7)

Supostamente, em situações de perigo como em guerras, com a incerteza da sobrevivência, surgem instintos primitivos não reprimidos por normas morais ou por autocensura, supérfluas em tais condições, sobretudo entre jovens. Ao longo da narrativa autobiográfica de Pedro, apreende-se que a boataria era uma constante entre os refugiados hispânicos, na busca de explicar o inexplicável ou o inaceitá- vel, na tentativa de entender os últimos acontecimentos (KAPFERER, 1993), denotando dúvidas e expectativas contraditórias.

[sic] Os boatos abundavam, a maioria pessimistas. A 5a. Coluna (os simpatizantes do franquismo que estavam infiltrados na zona legal) travalhava a todo vapor, sabotando nossa retaguarda e expandindo boatos derrotistas. Enfim, que a gente já dava como próxima nossa derrota. [...] Já estava escurecendo e fazia frio. Comimos o resto da comida, e pouco depois decidimos empreender a retirada, seguindo o fluxo de retirantes. (Pedro Brillas, [199-?]a, p. 73)

Caminharam durante toda a noite até La Jonquera, cidade próxima à fronteira francesa, percorrendo lentamente os $19 \mathrm{~km}$ de distância. Em certo momento, notaram novamente gente entrando e saindo de um grande galpão, próximo à estrada, carregando pacotes. A mesma cena anterior se repetia. Um depósito de alimentos do exército "checo (?)", 20 aparentemente abandonado, estava sendo saqueado, em umas poucas prateleiras de madeira ainda restavam caixas ou pacotes, enquanto, no centro do galpão, a maioria delas havia sido derrubada:

[sic] Esquecendo que não fazia muitas horas, quase fomos fuzilados, por ter entrado numa casa saqueada, mas vendo tanta gente, homens, mulheres, até crianças levando o máximo que podiam carregar, nós também procuramos algo que pudéssemos aproveitar. [...] 0 chão estava cheio de açúcar, cereais, caixas estruturadas de papelão, contendo sabão, velas, etc., tudo esparramado, com o pessoal pisando encima. Eu vi que um homem estava abrindo uma dessas caixas, o que dela tirava, latas de leite condensado. Fui até lá e consegui ainda pegar 2 latas. [...] Praticamente o que ainda estava por lá, eram produtos de limpeza, velas, inseticidas, etc. coisa que para nós não interessava. Só peguei mais sabonetes e 2 pastas para dentes e uma escova. [...] Antonio, também pouca coisa tinha conseguido. Sabão, velas, um pacote re-

20 O próprio autor colocou o ponto de interrogação, indicando a sua dúvida. 
bentado de macarrão e alguma pequena coisa. Na realidade, de novo tínhamos chegado tarde. (Pedro Brillas. Caderno 9, [199-?]b, p. 6-7)

Em tempos de guerra, há carência de gêneros alimentícios, que devem ser adquiridos, de maneira formal ou informal, pois a fome e o instinto de sobrevivência não levam em conta os códigos de ética, podendo "impelir os grupos humanos pelos mais estranhos caminhos" (CASTRO, 1965, p. 275).

O autobiógrafo prossegue o seu relato vivaz do êxodo, inimaginável por aqueles que nunca vivenciaram um exílio forçado multitudinário, e expressa as suas incertezas. Além disso, fala da sensação de "vazio", como se fosse um "autômato" seguindo a multidão:

[sic] Yo, me sentia como vacío. Casi que no pensaba, y andaba como un autómata, atrás de hombres y mujeres, que no conocía, mas que tenían una cosa en común, conmigo, el miedo al fascismo, a la guerra y a la muerte. [...] Todos nos sentamos o tumbamos en la carretera, en espera de reanudar la marcha. Notabamos que faltaba bien poco para llegar a nuestro DESTINO $(i)$ y nuestras esperanzas iban aumentando. Aquel prolongado alto, me pareció que fue decidido adrede21, para que tuviésemos tiempo de hacer nuestro exame de conciencia, o nuestras reflexiones, antes de abandonar España y entrar en Francia. (Pedro Brillas. 1965, p. 8, grifos nossos)

Transcorridos 26 anos desde aquele momento, em 1965, Pedro relembra os seus últimos pensamentos antes de deixar a terra natal e traça uma detalhada retrospectiva da sua vida até então, ${ }^{22}$ desde a sua infância em Barcelona, o relacionamento familiar, o seu primeiro amor por Lolita, uma vizinha da sua rua, a apreensão e tristeza da sua mãe, quando o filho se engajou na guerra, o apoio do seu irmão Andrés, nas trincheiras e campos de batalha, discorrendo também extensamente sobre

21 Expressamente, de propósito.

22 Devido à sua extensão, é impossivel transcrevê-la aqui. o momento mais triste da sua vida, ao visitar o seu irmão Juan, no hospital, ferido na guerra civil e com a perna amputada, o único da família que morreu em decorrência do conflito. Para finalizar, o autor recorda, com desapontamento, o desfecho, o sacrificio pessoal e as inúmeras vítimas fatais da guerra:

[sic] A grandes rasgos, recordé algunos momentos de mi campana, para comprobar con amargura, que de nada había valido mi entusiasmo y sacrificio. Lamentaba los inúmeros muertos que había visto, todos en balde. Franco, con sus ejércitos mercenarios, conseguía vencer. ¡Una vergüenza! ${ }^{23}$ Mas tarde pagarían cara su traición los que debían habernos ayudado y no hicieron. (Pedro Brillas. 1965, p. 25-26)

Para aqueles retirantes espanhóis, atravessar a fronteira franco-espanhola, além de aflorar a forte emoção do afastamento dos seus entes queridos, diante da proximidade do exílio, representaria uma ruptura com as suas raízes e cultura, deixando-os, literalmente, "sem o chão" da sua terra natal. Seguramente, combatentes antifranquistas como Pedro, perguntaram-se, muitas vezes, se não teria sido em vão o seu sacrificio, privações, fome, as milhares de vítimas por uma luta inglória, além do exílio forçado.

Pedro e Antonio, como milhares de refugiados passaram por La Jonquera, ${ }^{24}$ e aguardaram

23 Supõe-se que Pedro tenha se referido aos países democráticos, como França, Estados Unidos e Inglaterra, que não prestaram a ajuda esperada aos republicanos. E, mais especificamente, pode estar se referindo à União Soviética, que havia prometido apoio, porém aproveitou as circunstâncias para levar o ouro armazenado no Tesouro Público, com a desculpa de que cairia nas mãos dos totalitaristas, e jamais foi devolvido à Espanha. Cf.: BORONAT, 2010.

24 Cabe destacar que o Museu Memorial de l'Exili situa-se em La Jonquera, e, segundo o diretor da organização Jordi Font (durante diálogo informal em 10 de maio de 2014), os milhares de refugiados espanhóis, que se dirigiram a Perthus, na fronteira francesa, passaram por aquela rua, que fazia parte do antigo traçado da rota nacional 2 - ligação Madri-fronteira -, entre eles Pedro e Antonio. Portanto, a localização do MUME, em La Jonquera, lhe confere um status duplo de "lugar de memória" e "lugar da história", já que aquela localidade teria sido "la puerta del Exilio". (FONT, 2013, p. 68-79) 
três dias pela abertura da fronteira pelas autoridades francesas, conforme já aludido, passaram por revista, quando eram despojados de suas armas e joias. Em seguida, foram conduzidos para destino desconhecido, por gendarmes e soldados das tropas coloniais, aos empurrões e culatradas e ordens de "Allez-allez!" aos cansados, inclusive idosos e crianças, durante o percurso de cerca $30 \mathrm{~km}$, entre a cidade de Le Perthtus e o Camp d'Argelès, vencidos durante um dia inteiro de caminhada. Eram contraditórios os sentimentos em relação ao acolhimento inicial:

[sic] Francamente dava rabia. Es verdad que los franceses nos dejaron entrar en su país, para protegernos de los franquistas, cosa que tenemos que agradecer, pero era lamentable la manera que nos tratavan. Como si fuessemos un rebaño de animales, conducidos al curral. (Pedro Brillas, 1965, p. 3-4)

Já era noite, quando chegaram a um local na praia, com fogueiras, junto a homens, muIheres e crianças, animais domésticos, além de cavalos, burros, vacas e galinhas. Pedro e Antonio fizeram uma cova na areia, para se abrigarem do vento e do frio, e dormiram ali, ao relento, em pleno inverno europeu. Ao despertarem na manhã seguinte, perceberam a multidão crescente em seu entorno, e notaram que se encontravam cercados por arames farpados e soldados armados.

\section{Memórias, experiências e estratégias de sobrevivência: Camp d'Argelès-sur-Mer}

Os refugiados espanhóis descobriram que estavam detidos em um campo improvisado nas areias do litoral de Roussillon, sem nenhuma infraestrutura, nem água potável e latrinas, muito menos um teto para protegê-los das intempéries. Era o Camp d'Argelès-sur-Mer, como ficou conhecido e "odiado" pela multi- dão à mercê das arbitrariedades das autoridades francesas. 0 autobiógrafo retrata de forma contundente aquele "inferno", segundo suas palavras:

[sic] En realidad, todos o casi todos los que estábamos en el campo deseábamos el fin de la guerra y una solución $\mathrm{p} /$ nuestro caso. Lo que nadie quería era vivir en aquel infierno que si bien no tenía el peligro de las bombas o balas, tenía dentro de si el aspecto de la muerte, por hambre o falta de cuidados. ¿Cuántos españoles ya no habían muerto dentro de aquel cuadrilátero ${ }^{25}$ ¡ $Y$ los que habían de morir aún! (Pedro Brillas, 1965, p. 81)

Em suas últimas memórias (ca. 1999-2006), o autor relembra algo não contemplado em 1965: na primeira noite no campo, ao tentar dormir ao relento, na praia, ouviu um grito de um homem “Água!", repetida por outras vozes, em sua maioria, masculinas. Aquela palavra, Pedro a escutou diversas vezes, espaçadamente, naquela noite e com maior frequência nas sucessivas. A palavra “Água!" era gritada cada vez que uma pessoa apressada para fazer as suas necessidades se dirigia à praia, ou seja, era uma forma de pedir passagem, rapidamente, aos milhares de refugiados sentados ou deitados na areia, pelo caminho. Meses mais tarde, já fora do Camp d'Argelès, a palavra era utilizada, aos gritos, quando algum francês, gendarme, soldado, ou alguém com quem não simpatizasse ou que representasse ameaça se aproximava. Novamente, o autor registra uma estratégia, nesse caso coletiva, para atenuar as adversidades.

Naquele refúgio havia manifestações diversas e contraditórias naquelas condições desumanas: solidariedade, disputa por alimentos, roubos, assédios sexuais, prostituição, escambo. Conforme já exposto, inicialmente não havia nenhuma infraestrutura para protegê-los. As mulheres, em posições vexató-

25 Os campos também eram conhecidos por "cuadrilátero" ou “hipódromo". Cf.: ALTED, 2012. 
rias, nas praias, para fazerem as suas necessidades, protegiam-se dos olhares masculinos por outras mulheres. Logo após, foram instaladas bombas de água próximas à praia, que provocaram diarreia em todos, pois estava contaminada com os seus dejetos, além disso adoeciam por doenças como tifo, pneumonia, alguns faleciam, sobretudo crianças, eram também acometidos por pragas, como piolhos, pulgas e sarnas, por falta de higiene. Enfim, os refugiados sofreram toda espécie de humilhações, privações e doenças.

[sic] Si bien los días eran más o menos todos iguales en verdad un grave acontecimiento se había propagado por el campo. ¡DIARREA! El agua que usábamos $\mathrm{p} /$ beber y comer subida por las bombas, que no era sino agua del mar, trajo un surto de epidemia de grandes consecuencias. A cualquier momento, en cualquier lugar la gente sentía fuertes dolores de barriga y tenia que correr hacía la playa (no había otro lugar) para desahogarse. Era un correr de hombres, mujeres, niños, muchos que tenían su acampamento algo mas separado de la playa no conseguían llegar, y o bien bajaban los pantalones y se aliviaban en cualquier lugar, a pesar de los protestos o risadas, o miradas indiscretas cuando se trataba de mujeres, o bien se cagaba en los pantalones. Fueron días terribles. Había gente que por temor a no tener tiempo, se quedaban cerca de la playa, horas y horas es espera del momento agudo. Durante las noches, oíamos blasfemias, gritos y ruidos de lucha. Era una pesadilla. Nadie escapaba a aquel desagradable mal. Los que se reían al primer día, recibieron después la gargallada de los otros. (Pedro Brillas, 1965, p. 90-91, grifo da fonte)

Notícias e rumores infundados e pouco críveis eram constantes, devido às incertezas do futuro dos refugiados espanhóis. Alguns otimistas, prevendo uma reviravolta na iminente derrota na guerra, outros pessimistas, e ainda:

[sic] Encuanto esperábamos tuvimos oportunidad de oir los más diversos comentarios. Deciase que iban a repartir comida caliente otros decían que iban a darnos pan y algo más $\mathrm{p} /$ acompañar. Habia quien decía que nos darían comida $\mathrm{p} /$ nosotros cocinar. Hacianse también comentarios s/nuestra situación y nuestro futuro. Enquanto alguien pretendía que en breve nos sacarían de ali $p /$ repartirnos $p /$ toda Francia, había otros que decían que nos iban a llevar hacia el frente del centro en España. Los mas pesimistas o quizás los confusionistas profesionales, insinuaban que nos entregarian a Franco. Ya se decía que en frente al nuestro había otro campo, en donde eran llevados los que deseaban volver a España. (Pedro Brillas, 1965, p. 62-63)

E ainda: [sic] Naturalmente pude oir muchos bulos o comentarios y como dijo Antonio, cual más extravagante, aunque verosimiles máximo $\mathrm{p} /$ una mentalidad como la de la mayoría de los refugiados, hambrientos y desesperados [...] (Pedro Brillas, 1965, p. 81).

A França sofria as consequências da crise dos anos de1930, portanto, o exílio republicano representava um problema político e econômico. Os franceses objetivavam livrar-se daquela imensa multidão de famintos e flagelados pela guerra civil. Em agosto de 1939, mais da metade havia retornado à Espanha, muitos foram torturados e fuzilados, ou levados a campos de trabalho forçado. Outros se engajaram na Legião Estrangeira, em outros países, como Antonio que, após a derrota antifranquista na Guerra Civil Espanhola, foi alocado na Indonesia, permanecendo Pedro sozinho, sem família e amigos, pela primeira vez.

Outros saíram do campo, contratados por agricultores das imediações; alguns deixaram o lugar por terem parentes na França que se responsabilizariam por eles; alguns outros emigraram para o México. Como as condições do campo melhoraram, com a instalação de alojamentos, latrinas, e mais espaço com a saída de muitos, Pedro tardou em se decidir a sair.

Afinal, integrou-se às Compagnies de Travailleurs Étrangers (Companhias de Trabalhadores Estrangeiros), também conhecidas como 
Compagnies de Travailleurs Espagnols (Companhias de Trabalhadores Espanhóis), denotando que a maioria era composta por espanhóis. Essas companhias eram uma espécie de "reservatorio" de mão de obra estrangeira gratuita ou em troca de salários miseráveis (EGGERS, 1995). Pedro resume a sua estadia no campo entre 8 de fevereiro e 15 de setembro de 1939, e o momento de sua saída:

[sic] Foram 220 dias, passando frio, fome, comido por piolhos e pulgas, com disenteria, sarna e muitas humilhações, mal vestido e dormindo na areia. Entrei ferido, saí curado, não pelos curativos recebidos no campo. Entrei esperançoso. Saí decepcionado.

Amaldiçoando os franceses pelos maus tratos, desde que cruzei a fronteira, onde a primeira palavra aprendida em francês foi “ALLEZ-ALLEZ"! Agora, no trem renasciam minhas esperanças. Só lamentava a nova Guerra. (Pedro Brillas, ca. entre 1999 e 2006, p. 19, cap. 4)

\section{Algumas considerações}

La Retirada foi o êxodo republicano espanhol massivo de fevereiro de 1939 realizado sob os bombardeios franquistas e da Legião Condor nazista, durante os quais os retirantes correram perigos, eram acometidos por incertezas, encontros impensáveis, recorriam a estratégias para aplacar a fome típica das guerras. Esperançosos de encontrar segurança e liberdade garantida pela República Francesa, terra de asilo, e considerado um país fraterno para os republicanos, foram recebidos de forma brutal e direcionados a campos de concentração destinados aos estrangeiros “indesejáveis", sobretudo aos refugiados espanhóis, além de judeus, testemunhas de Jeová, ciganos e antinazistas, durante a Segunda Guerra Mundial.

Cabe ressaltar que esses campos eram também conhecidos como campos de "internamento", como as autoridades francesas pre- feriram denominá-los. Independentemente da alcunha utilizada, deve-se considerar que os estrangeiros "indesejáveis" foram detidos em regime concentracionário, vigiados por soldados armados, geralmente sem o direito de ir e vir, mesmo sem terem cometido crime algum, e que para tanto foi criado um sistema complexo e multifacetado, com várias modalidades de detenção daqueles estrangeiros, que perdurou entre 1939 e 1946, com o objetivo de agrupá-los, controlá-los e de excluí-los do convívio na sociedade francesa (PESCHANSKI, 2002). Na contemporaneidade, a alcunha como campos de concentração é hoje reconhecida na França, sendo "um dever da História e da Memória aos milhares de internados e albergados [...] admitir que a França naquela época foi um estado fascista com campos de concentração". Ou seja, o país faz mea-culpa em relação ao tratamento aos refugiados (LE CAMP DE CONCENTRATION DU VERNET D'ARIĖGE 1939-1944, s/d.).

O Camp d'Argelès foi um dos mais emblemáticos entre os inúmeros campos que se espalharam no país, por onde passaram milhares de espanhóis esperançosos na busca de segurança e liberdade, inicialmente inacessiveis para eles, naquele país. Muitos encontraram a morte ali, devido às precárias condições a que foram submetidos. Durante a ocupação nazista da França, milhares de refugiados espanhóis foram entregues à Gestapo ${ }^{26}$ e levados, nos assim denominados "trens da morte", aos campos de extermínio nazistas; onde morreram cerca de 5.000 hispânicos (ALTED, 2012; AMICALE DE MAUTHAUSEN, s/d.). Porém, outros sobreviveram, entre eles Pedro Brillas, que nunca esqueceu os 220 dias de adversidades passadas ali.

Essas recordações de Pedro Brillas presentes na sua narrativa autobiográfica permitem um relevante e rico diálogo com a Historiografia, como discorrido ao longo desse trabalho. A

26 Geheime Staatspolizei (polícia secreta alemã). 
memória de si de populares reflete experiências pessoais e coletivas, articulam questões de âmbito privado e público, e rompem ocultamentos e silêncios impostos por regimes totalitários. Além disso, espelham sensibilidades, temáticas singulares, e trazem um colorido a acontecimentos históricos. Por vezes, a escrita de si permite um diálogo solitário consigo mesmo, um apoio psicológico nas horas de desamparo e de incertezas, além da autorreflexão sobre as suas inquietações.

Nos episódios aqui em questão, os seus escritos espelham a memória e experiências de sujeitos históricos, somando detalhes e subjetividades enriquecedores à formação da memória coletiva de um evento dramático da Historiografia espanhola e francesa, ainda hoje em construção, sustentada por meio da voz oral e escrita de anônimos, que vem ganhando visibilidade à luz das investigações em desenvolvimento, e outras, ainda a serem realizadas, para que este passado trágico do século $X X$ não seja esquecido, nem silenciado.

\section{Referências}

ALTED, Alicia. La voz de los vencidos: el exilio republicano de 1939. [E-book] Madrid: Santillana Ediciones Generales, 2012.

AMICALE DE MAUTHAUSEN. Déportés, Familles et Amis. Disponivel em: <http://campmauthausen. org/>. Acesso em: 8 mar. 2015.

ARANCIBIA, Mercedes. Francia: 75 aniversario de La Retirada de los republicanos españoles. Periodistas en Español, Madri, 27 fev. 2014. Disponivel em: <http://periodistas-es.com/espana75-aniversariode-la-retirada-29955>. Acesso em: 5 jan. 2015.

ARFUCH, Leonor. 0 espaço biográfico: dilemas da subjetividade contemporânea. Tradução de Paloma Vidal, Rio de Janeiro: Ed. UERJ, 2010a.

El espacio biográfico: dilemas de la subjetividad contemporánea. 1. ed., 3. reimp. Buenos Aires: Fondo de Cultura Económica, 2010b.
ARTIÈRES, Philippe. Arquivar a própria vida. Estudos Históricos, Rio de Janeiro, v. 11, n. 21, 1998.

Arquivar-se: a propósito de certas práticas de autoarquivamento. Arquivos pessoais. In: TRAVANCAS, I.; ROUCHOU, J.; HEYMANN, L. (Orgs.). Arquivos pessoais: reflexões multidisciplinares e experiências de pesquisa. Rio de Janeiro: Editora FGV, 2013.

AVELAR, Alexandre de Sá; SCHMIDT, Benito Bisso. (Orgs.). Grafia da vida: Reflexões e experiências com a escrita biográfica. São Paulo: Letra e Voz, 2012.

BORONAT, Oscar. Quatro caminhos. São Paulo: Ed. do Autor, 2010.

BUADES, Josep M. A guerra civil espanhola. São Paulo: Contexto, 2013.

CASANOVA, Julián. España partida en dos: breve historia de la Guerra Civil Española. [E-book] Barcelona: Critica, 2013.

CASTILLO GÓMEZ, Antonio. Escritura y clases subalternas: una mirada española. Oiartzun: Sendoa, 2001.

CASTRO, Josué de. Geografia da fome. O dilema brasileiro: pão ou aço. 9. ed. São Paulo: Brasiliense, 1965.

CHARTIER, Roger. (Dir.). La correspondence, les usages de la lettre au XIXe siècle. S.l.: Flayard, 1991.

DEPORTADOS. Hablan los expertos. Disponivel em: <http://deportados.es/expertos $>$. Acesso em: 15 jan. 2015.

EGGERS, Christian. L'internement sous toutes ses formes: approche d'une vue d'ensemble du système d'internement dans la zone de Vichy. Le Temps des "indésirables". Sur quelques camps d'internement français. Le Monde juif, Revue d'histoire de la Shoah, Paris, n. 153, p. 10, jan./avr. 1995. Disponível em: <http://www.memorialdelashoah.org/wpcontent/uploads/2016/05/texte-reference-memorial-shoah-eggers.pdf>. Acesso em: 8 mar. 2018.

E-XILIAD@S. Proyect. Ministerio de Empleo y Seguridad Social. Secretaría General de Inmigración y Emigración. Disponivel em: <http://www.exiliadosrepublicanos.info/es>. Acesso em: 15 jan. 2015. 
FONT, Jordi. Le Musée Mémorial de l'Exil de La Jonquera (MUME). Témoigner, Entre histoire et mémoire, Bruxelas, n. 115, p. 68-79, mar. 2013. Disponivel em: <https://temoigner.revues.org/455>. Acesso em: 25 jan. 2016.

FOUCAULT, Michel. A escrita de si. In: MOTA, Manoel Barros da. (Org.). Ditos e Escritos. V - Ética, sexualidade e política. Tradução de Elisa Monteiro e Inês Autran Dourado Barbosa. 2. ed. Rio de Janeiro: Forense Universitária, 2006. p. 143-162.

GAILLARD, Valèria. Un inèdit de Capa. El Punt Avui, Cultura, Barcelona, 4 jun. 2015. Disponivel em: <http://www.elpuntavui.cat/noticia/article/5-cultura/19-cultura/863311-.html?cca=1>. Acesso em: 4 jun. 2015.

GOMES, Angela de Castro. (Org.). Escrita de si, escrita da História. Rio de Janeiro: Editora da Fundação Getúlio Vargas, 2004.

INSTITUTO ANTÔNIO HOUAISS. Grande Dicionário Houaiss da Língua Portuguesa. Rio de Janeiro: Objetiva, 2012. Disponivel em: <http://houaiss.uol. com.bry. Acesso em: 21 fev. 2015.

KAPFERER, Jean-Noël. Boatos: a mais antiga mídia do mundo. Tradução de Ivone S. R. Maya. Rio de Janeiro: Forense Universitária, 1993.

KAPLAN, Harold I.; SADOCK, Benjamin J. Compêndio de psiquiatria: ciências comportamentais. 6. ed. Tradução de Dayse Batista. Porto Alegre: Artes Médicas, 1993.

LANIER, Valérie. La liberté d'expression dans les camps de concentration français: le cas de réfugiés espagnols en 1939. Dossier de recherche. Université de Bourgogne - Faculté de Droit et de Sciences Politiques, 2000-2001.

LE CAMP DE CONCENTRATION DU VERNET D'ARIÈGE 1939-1944. Le camp de concentration du Vernet d'Ariège \& son Amicale. Disponivel em: $\leq$ http:// www.campduvernet. eu/>. Acesso em: 4 mai. 2015.

LLECH, Louis; ISAMBERT, Louis. L'Exode d'un peuble. Filme - documentário (36 min). Club des Amateurs cinéastes du Roussillon (CACR), França, fev. 1939. Disponivel em: <https://www.youtube.com/watch?-
v=D-DVuB1nyhE $>$. Acesso em: 18 jan. 2015.

LEJEUNE, Philippe. O guarda-memória. Revista Estudos Históricos, Rio de Janeiro, v. 10, n. 19, p. 111120, jul. 1997. ISSN 2178-1494. Disponível em: <http:// bibliotecadigital.fgv.br/ojs/index.php/reh/article/ view/2042/1181>. Acesso em: 8 mar. 2018.

O pacto autobiográfico: de Rousseau à internet. Tradução de Jovita Maria Gerheim Noronha e Maria Inês Coimbra Guedes. Belo Horizonte: Editora da UFMG, 2008.

L'ILLUSTRATION. Paris, no. 5.007, 18 fev. 1939. Cf.: MUME. Museu Memorial de l'Exili. Disponível em: <http://www.museuexili.cat/>. Acesso em: 29 jun. 2016.

MICKAEL, Martins. La Retirada. Vídeo sobre a Retirada espanhola em 1939. Disponivel em: <http://www. eclectique.net/histoires histoire/themes5.html $>$. Acesso em: 24 mar. 2015.

MOLINA, Angela. Walter Benjamin, última parada. El País, Madrid, 13 jul. 2012. Disponivel em: <http:// elviajero.elpais.com/elviajero/2012/07/13/ actualidad/1342175697 330630.html>. Acesso em: 20 jan. 2016.

MONTANDON, Alain. Livre de l'hospitalité. Paris: Bayard, 2004.

O livro da hospitalidade: acolhida do estrangeiro na história e nas culturas. São Paulo: Senac, 2011.

MUME. Museu Memorial de l'Exili. Disponível em: <http://www.museuexili.cat/>. Acesso em: 4 jan. 2015.

ORWELL, George. Lutando na Espanha. Homenagem à Catalunha, recordando a guerra civil espanhola e outros escritos. Tradução de Ana Helena Souz. São Paulo: Globo, 2006.

PÀMIES, Teresa. Los que se fueron. Barcelona: Martínez Roca, 1976.

PESCHANSKI, Denis. La France des camps: l'internement 1938-1946. Mayenne: Gallimard, 2002.

POLLAK, Michael. Memória, esquecimento, silên- 
cio. Revista Estudos Históricos, Rio de Janeiro, v. 2, n. 3, p. 3-15, jun. 1989. ISSN 2178-1494. Disponivel em: <http://bibliotecadigital.fgv.br/ojs/index.php/reh/ article/view/2278/1417>. Acesso em: 8 mar. 2018.

POLLAK, Michael. Memória e identidade social. Revista Estudos Históricos, Rio de Janeiro, v. 5, n. 10, p. 200-215, jul. 1992. ISSN 2178-1494. Disponivel em: <http://bibliotecadigital.fgv.br/ojs/index.php/reh/ article/view/1941>. Acesso em: 8 mar. 2018.

ROMERO SALVADÓ, Francisco J. A guerra civil espanhola. Tradução de Barbara Duarte. Rio de Janeiro: Jorge Zahar, 2008.

SAN GEROTEO, Raymond. Les Oliviers de l'exil. Sobrevivir - Collection dirigée par André Gabastou. Pau: Cairn, 2012.

SILVA, Wilton C. L. Espelho de palavras: escrita de si, autoetnografia e ego-história. In: AVELAR, Alexandre de Sá; SCHMIDT, Benito Bisso. (Orgs.). Grafia da vida: reflexões e experiências com a escrita biográfica. São Paulo: Letra e Voz, 2012. p. 39-61.

TRAVANCAS, Isabel Siqueira; ROUCHOU, Joëlle; HEYMANN, Luciana. Arquivos pessoais: reflexões multidisciplinares e experiências de pesquisa. Rio de Janeiro: FGV, 2013.
ZARAGOZA OCAÑA, Diana. Exilio 1939: testimonios de familia. Archivo de correspondencia personal de Francisco Floreal Ocaña Sánchez. México: Ayala, 2008.

ZIFF, Trisha (Dir). The mexican suitcase. Filme - documentário (86 min). Produtores: Eamon O'Farrill, Trisha Ziff, Paco Poch. 2011.

\section{Fonte}

Pedro Brillas. Exilio. Texto manuscrito (não publicado), 1965. Acervo pessoal.

Lembranças. Caderno 10. Texto manuscrito (não publicado), 1998. Acervo pessoal.

Lembranças de Pedro Brillas. Texto datilografado (não publicado), ca. entre 1999 e 2006, p. 36 (cap.2). Acervo pessoal.

Caderno 8. Texto manuscrito (sem título, não publicado), [199-?]a. Acervo pessoal.

Caderno 9. Texto manuscrito (sem título, não publicado), [199-?]b. Acervo pessoal.

Recebido em: 14.11.2017

Aprovado em: XX.03.2018

Geny Brillas Tomanik é Doutora em História Social na Pontificia Universidade Católica de São Paulo. Mestre em Hospitalidade na Universidade Anhembi-Morumbi SP. e-mail: gbtomanik@gmailcom.

Rua Rio Xingu, 111 - Cond. Fazenda São Joaquim, Vinhedo/SP. Telefone: (19) 981376591 